УДК 349.22

DOI https://doi.org/10.32837/pyuv.v1i3(28).344

Д. I. Cipoxa

кандидат юридичних наук, дочент,

доцент кафедри трудового права та права соціального забезпечення Київького національного університету ілені Тараса Шевченка

\title{
ЗНАЧЕННЯ АКТІВ ЛОКАЛЬНОЇ НОРМОТВОРЧОСТІ В РЕГУЛЮВАННІ ПРАЦІ
}

Підвищення ролі локальних нормативно-правових актів у правовому регулюванні трудових відносин зумовлено зменшенням впливу держави на виробничі процеси внаслідок постійного зменшення частки державної власності на засоби виробництва. Так, кількість державних підприємств в Україні з 1 липня 2018 р. по 1 липня 2019 р. зменшилась на 2\% (до 3789 ), а порівняно iз 2004 р. - на $43 \%$. У поєднанні із процесами децентралізації державного управління вказане зумовлює зростання потреби в локальному правовому регулюванні праці, що, разом із недостатньою розробленістю вказаної проблематики в науці трудового права, зумовлює актуальність цієї статті.

Проблеми визначення ролі та місця локальних нормативно-правових актів у регулюванні праці розглядали у своїх роботах В.С. Венедіктов, С.В. Венедіктов, І.М. Іншин, В.Л. Костюк, I.А. Красюк, С.С. Лукаш, Р.А. Майданник, O.О. Момоток, В.В. Панченко, С.М. Прилипко, П.М. Рабінович, В.В. Форманюк, Є.О. Харитонов, H.M. Хуторян, Г.І. Чанишева, О.М. Ярошенко й інші науковці. Водночас варто зазначити, що динамічні зміни змісту трудових відносин, спричинені динамічним розвитком інформаційних технологій, а також активізація законотворчої роботи, наслідком якої має стати затвердження довгоочікуваного Трудового кодексу України, зумовлюють необхідність вироблення нового бачення значення актів локальної нормотворчості в регулюванні праці та слугують підтвердженням необхідності наукових розвідок за вказаним напрямом.

Мета статті - на підставі аналізу положень доктринальних джерел і нормативно-правових актів сформулювати значення локальної нормотворчості в регулюванні праці в сучасних умовах державотворення.

Суспільні відносини, що виникають у процесі застосування праці, переважно врегульовані чинним законодавством у централізованому порядку. Тому до сфери локальної нормотворчості віднесено лише деякі сторони цих відносин, які відображають їхню специфіку на конкретному підприємстві (наприклад, встановлення правил внутрішнього трудового розпорядку, графіка робіт тощо). Як наслідок, одна з особливостей правової регламентації праці полягає саме в тому, що законодавець, установлюючи загальні правила поведінки для учасників трудових відносин, надає сторонам у процесі формування умов праці можливість визначати конкретні норми з урахуванням сформованих на даний момент суб'єктивних і об'єктивних чинників (фінансово-господарських можливостей підприємства, професійної підготовки працівників тощо). Відповідно й особливість системи нормативних актів у галузі трудового права полягає в наявності в їхньому складі значної кількості локальних норм, установлених безпосередньо на підприємствах за погодженням між керівником і профспілкою або трудовим колективом чи уповноваженою ним особою. Призначення таких локальних нормативних актів полягає в тому, щоб в установлених умовах праці та їі оплати (особливо щодо додаткової оплати - преміювання тощо) виразити специфіку даного підприємства [1, с. 145]. Отже, локальні форми вираження трудового права - це ті корпоративні документи та локальні акти, які ухвалюються безпосередньо на підприємствах, в організаціях чи установах та які набувають чинності, якщо ухвалені в установленому законом порядку. Локальні нормативні акти виступають юридичною формою вираження та закріплення волі рівноправних суб'єктів локального регулювання - волі трудових колективів, уповноважених органів підприємств та профспілок. 3 огляду на це, реалізуючи свої права у сфрері регулювання соціально-трудових відносин, на підприємствах у межах компетенції укладаються, затверджуються, видаються головним чином такі локальні нормативні акти, як: колективний договір; правила внутрішнього трудового розпорядку; інші локальні нормативні акти в галузі праці (положення, інструкції, графіки, технічні норми і правила тощо).

Розробка й ухвалення локальних актів сьогодні набули значного поширення. Деякі з них $€$ результатом нормотворчої діяльності тільки роботодавця (наприклад, ті, що опосередковують технологічний процес в організації), інші можуть ухвалюватися роботодавцем за участю представників трудового колективу (спільно або за погодженням). Дана особливість є однією із ключових ознак розрізнення локальних актів. Акти, які ухвалюються роботодавцем самостійно, виражають одноособову волю роботодавця, інші мають договірний характер і виражають узгоджену волю 
роботодавця і трудового колективу. Це є свідченням того, що робота зі створення таких норм, яка провадиться всередині підприємства, є досить вагомою та значною для загального правового регулювання відносин у сфері праці.

Одним із перших, хто окреслив проблему колективного договору, був Л.С. Таль, який виокремив його зі сфери інституту цивільного права. Зазначений правовий документ, на його думку, зародився як приватноправова угода, яка першочергово розглядалася та регулювалася в рамках цивільного права. Адже римське право розглядало договір про працю як договір про оплатне користування - locatio conduction (оплатне користування чужою річчю, чужою робочою силою, результатами чужої праці). Згодом він довів, що цей договір має специфічну природу, є договором sui generis, який відноситься до сфери промислового робочого права - прообразу галузі трудового права. Отже, Л.С. Таль запропонував специфічну конструкцію договору, надав його розгорнуту характеристику й обгрунтував необхідність законодавчого регулювання суспільних відносин, які безпосередньо пов'язані з укладанням і виконанням колективного договору. Ще в дореволюційний період Л.С. Таль вказував також на те, що колективний договір варто відносити до нормативних угод, під якими він розумів результати позазаконодавчої правотворчості окремих соціальних кіл у межах властивої їм здатності до самовизначення (соціальна автономія) [2, с. 60].

Тоді як М.М. Марченко сформулював дещо інше поняття нормативно-правового договору, роблячи акцент на інших його ознаках. По-перше, нормативно-правовий договір, на його думку, містить правові норми-правила загального й обов'язкового характеру. Отже, нормативний договір (різновидом якого є колективний договір), на відміну від звичайного договору, що є актом реалізації права, містить норми, "розраховані не на окреме разове відношення чи на будь-яких конкретних осіб, а на безліч відносин певного виду й індивідуально неперсоніфікованих осіб, які підпадають під їхню дію» [3, с. 183.]. По-друге, нормативний договір може містити не тільки норми, але і принципи права. По-третє, нормативний договір є актом правотворчості, а не актом правозастосування - і це найголовніше. Особливість нормативного договору полягає ще й у тому, що він - не просто акт правотворчості, як будь-який інший нормативно-правовий акт, а акт, що породжується його особливим різновидом - договірною правотворчістю, що у спеціальній літературі називається «погоджувальною правотворчістю" [4, с. 72].

У теорії права під договором розуміється угода двох або більше осіб щодо здійснення конкретних дій і встановлення регулюючих такі дії взаємних прав і обов'язків, виконання яких забезпечується можливістю державно-організаційного примусу. Отже, договірна правотворчість, тобто правотворчість, в основі якої лежить процес узгодження і приведення до спільного знаменника двох або більше відносно самостійних автономних волевиявлень, породжує і відповідний характеру цього процесу - договірний акт - нормативно-правовий договір, що містить договірні принципи і норми, які відповідають його договірній природі і характеру [5, с. 288-289]. За такого розуміння характеристик нормативного договору його різновидом може вважатися і колективний договір, тому що йому також властиві всі перелічені ознаки.

Так, відповідно до положень Закону України «Про колективні договори та угоди» [6], колективний договір укладається на основі чинного законодавства, прийнятих сторонами зобов'язань із метою регулювання виробничих, трудових і соціально-економічних відносин, узгодження інтересів працівників та роботодавців. Колективний договір укладається на підприємствах, в установах, організаціях незалежно від форм власності i господарювання, які використовують найману працю і мають право юридичної особи.

Колективний договір укладається між власником або уповноваженим ним органом, з однієї сторони, й однією або кількома профспілковими чи іншими уповноваженими на представництво трудовим колективом органами, а за відсутності таких органів - представниками трудящих, обраними й уповноваженими трудовим колективом, - 3 іншої сторони. Зміст колективного договору, відповідно до Закону України «Про колективні договори та угоди» [6], визначається сторонами в межах їхньої компетенції. Колективний договір може передбачати додаткові порівняно із чинним законодавством і угодами гарантії, соціально-побутові пільги, забезпечує гнучкість i повноту цього процесу у сфері праці. Виявлення й усунення прогалин спрямовано на формування певної завершеності правової регламентації трудових відносин в організаціях різних форм власності й організаційно-правових форм діяльності.

Отже, у широкому сенсі про колективний договір можна говорити як про юридичний засіб, що використовується у формі свідомих дій сторін, що домовляються, які вчиняються для досягнення гармонії у стосунках, що виникають і розвиваються в контексті виробничої діяльності. Навіть більше, у такий формат розуміння колективного, або корпоративного договору може бути включена вся сукупність способів, за допомогою яких досягається така цілепокладаюча гармонія інтересів. Інакше кажучи, це не тільки воля, виражена в нормах корпоративного договору, але і трудова активність людини, її перетворюючі дії. У цій ситуації колективний договір виступає, з одного боку, як абстрактно логічна модель збалансованого інтер- 
есу, а з іншого - як реальний механізм або процес його досягнення. У цьому ракурсі колективний договір може бути розглянутий як той юридичний засіб, з допомогою якого досягається компроміс, який визначає умови досягнення гармонії у виробничому процесі та пом'якшує зіткнення інтересів роботодавця і працівників [7, с. 29].

Вищенаведене явно підкреслює нормативний характер колективного договору, тобто колективний договір - це правовий акт, що укладається 3 метою регулювання соціально-трудових відносин на підприємстві (в організації) між найманими працівниками та роботодавцем для узгодження їхніх інтересів. Як наслідок, колективний договір за своєю природою є актом договірної правотворчості, а не актом реалізації права. Відповідно термін «договір» вказує тільки на спосіб ухвалення даного правового акта.

Отже, колективний договір як локально-правове джерело конкретизує та доповнює централізовані приписи з урахуванням галузевих особливостей виробництва, заповнюючи тим самим прогалини у праві. Локальні норми, які містяться в колективному договорі, наділені властивостями, які характерні для норм, установлених законодавством: вони обов'язкові до виконання, розраховані на багаторазове застосування, поширюються на необмежене коло осіб.

В умовах соціально-економічних перетворень у нашій державі колективний договір виступає ефективною формою локального регулювання умов і оплати праці безпосередньо на підприємствах (в установах, організаціях), де вирішуються важливі питання матеріального та морального стимулювання. На переконання Б.А. Архипової, колективний договір виступає свого роду кодексом локальних норм права, який схвалений усім трудовим колективом працівників [8, с. 22].

Важливе місце в системі нормативних актів, що регулюють трудову дисципліну, посідають правила внутрішнього трудовою розпорядку. Вони мають на меті сприяти вихованню працівників, зміцненню трудової дисципліни, належній організації праці, раціональному використанню робочого часу та високій якості роботи. Так, відповідно до ст. 142 Кодексу законів про працю (далі - КЗПП) України, трудовий розпорядок в організації визначається правилами внутрішнього трудового розпорядку, які затверджуються трудовими колективами за поданням власника або уповноваженого ним органу і профспілкового комітету на основі типових правил [9]. Отже, правила внутрішнього трудового розпорядку - локальний нормативний акт спільного волевиявлення сторін трудових відносин підприємств, установ та організацій усіх форм власності, що врегульовує внутрішні, організаційно-правові аспекти відносин між роботодавцем і працівниками від початку укладання трудового договору до припинення трудових відносин, сприяє окресленню кола обов'язків, прав і гарантій, які є спільними для всіх категорій працівників або для їх окремих груп у процесі реалізації їхньої трудової функції.

На додачу до правил внутрішнього трудового розпорядку й окремих дисциплінарних статутів, які діють в деяких галузях економіки та трудової діяльності та мають погоджувальний характер, діяльність працівників і службовців детально регламентується іншими погоджувальними актами, а також технічними правилами й інструкціями, графіками, посадовими інструкціями 3 різних виробництв і професій (інструкція з охорони праці, пожежної безпеки), іншими нормативними актами. Відповідні акти, на відміну від правил внутрішнього трудового розпорядку, містять спеціальні правові норми, які регулюють або працю окремих працівників залежно від характеру виконуваної ними трудової функції, або окремі умови трудового договору. Так, наприклад, актами відповідного регулювання є графіки змінності (ст. 57 КЗпП); переліки робіт, на яких працівникам повинна бути надана можливість приймати їжу протягом робочого часу (ст. 66); графіки черговості надання відпусток (ст. 79 КЗПП); рішення з питань оплати праці (положення, норми праці, розцінки, тарифні сітки, ставки, схеми посадових окладів, умови запровадження та розміри надбавок, доплат, премій, винагород та інших заохочувальних, компенсаційних і гарантійних виплат, якщо колективний договір на підприємстві, в установі, організації не укладено) (ст. 97 КЗпП); комплексні заходи щодо охорони праці (ст. 161 КЗпП) [9] тощо.

Технічні правила й інструкції, що конкретизують трудові обов'язки працівників та встановлюють спеціальні обов'язки, оформлюються в низці випадків як правила технічної експлуатації, які видаються міністерствами (відомствами). У свою чергу, технічні інструкції, на відміну від технічних правил, містять переважно приписи про порядок ведення виробничого процесу, про основні вимоги поводження з машинами, про порядок догляду за машинами, а також деякі інші приписи щодо техніки безпеки.

Отже, беручи до уваги, що технічні норми регулюють відношення людей до сил природи, до засобів праці, визначають технічні прийоми праці, послідовність та технічний взаємозв'язок окремих виробничих операцій, можна констатувати, що технічні норми, будучи врегульованими відповідними нормативними актами, уже не є «технічними» нормами, оскільки їх застосування визначається державою, вони стають юридичним обов'язком для працівників [10, с. 115].

Отже, хоча всі ці джерела мають різне найменування та регулюють різні види суспільних 
відносин, їм притаманні деякі спільні риси. Усі вони - результат нормотворчої діяльності, яка здійснюється на підприємстві. За їх допомогою оформляються локальні правові норми, тобто такі, що мають нормативний характер, веління уповноваженого органу управління (зокрема, погоджені із профспілковим комітетом), спільні рішення роботодавця та профспілкового комітету, волевиявлення трудового колективу. Саме ці норми, закріплені в зазначених документах, є результатом відповідної правової спеціалізації, встановлюються 3 метою конкретизації та деталізації, обліку своєрідності конкретних відносин.

Виходячи 3 наведеного вище, значення актів локальної нормотворчості в регулюванні праці простежується у трьох основних аспектах: як прояв принципу демократичності трудових відносин, відповідно до якого потреби й інтереси працівника безпосередньо впливають на нормативний зміст трудових відносин; як засіб виховання правової культури працівника і роботодавця, а також їхньої взаємної відповідальності у трудоправових відносинах; як реалізація вимоги правової визначеності, відповідно до якої суб'єктам трудових відносин має бути надана можливість легкого доступу до правових приписів, що визначають вимоги до їхньої поведінки, а також можливість використати локально-правові норми для захисту своїх прав та інтересів у разі необхідності.

\section{Jimepamypa}

1. Советское трудовое право : учебник / под ред. Н.Г. Александрова. Москва : Юрид. лит., 1972.576 с.

2. Таль Л.С. Очерки промышленного рабочего права. Москва : Московское научное издательство, 1918. $225 \mathrm{c}$.

3. Баптин М.И. Сущность права (современное нормативное правопонимание на грани двух веков). Саратов : СГАП, 2001. 416 с.

4. Иванов В.В. Общие вопросы теории договора : монография. Москва : Эдиториал УРСС, 2000. $160 \mathrm{c.}$

5. Марченко М.М. Источники права : учебное пособие. Москва:ТК «Велби»; изд-во «Проспект», 2005.760с.

6. Про колективні договори та угоди : Закон України № 3356 від 1 липня 1993 р. Відомості Верховної Ради України. 1993. № 36. Ст. 361.

7. Баева С.С. Коллективный договор как самостоятельный правовой институт : дис. ... канд. юрид. наук: 12.00.05. Санкт-Петербург, 2006. 171 с.

8. Архипова Б.А. Коллективный договор на предприятии : монография. Москва : Знание, 1975. 32 с.

9. Кодекс законів про працю України від 10 грудня 1971 р. № 322-VIII. Відомості Верховної Ради УРСР. 1971. Додаток до № 50. Ст. 375.

10. Левиант Ф.М. Нормативные акты, регулирующие труд рабочих и служащих. Ленинград : ЛГУ, 1960. $136 \mathrm{c}$.

\section{Анотація}

Сіроха Д. І. Значення актів локальної нормотворчості в регулюванні праці. - Стаття.

Стаття містить аналіз сутності актів локальної нормотворчості та їхнього впливу на правове регулювання праці. Автор розглядає концепції та підходи до локальної нормотворчості в доктрині трудового права. Стаття містить авторську концепцію значення локальної нормотворчості, яка сформована на підставі аналізу правових актів і результатів наукових досліджень.

У статті зазначено, що до сфери локальної нормотворчості віднесено лише певні сторони трудових відносин, які відображають їхню специфіку на конкретному підприємстві (наприклад, встановлення правил внутрішнього трудового розпорядку, графіка робіт тощо). Локальні правові норми мають нормативний характер. Вони являють собою веління уповноваженого органу управління, спільні рішення роботодавця та профспілкового комітету, волевиявлення трудового колективу. Ці норми, закріплені в зазначених документах, є результатом відповідної правової спеціалізації, встановлюються з метою конкретизації та деталізації, урахування своєрідності конкретних відносин. Особлива увага приділена правовій природі правил внутрішнього трудового розпорядку, технічних правил та інструкцій.

Автор формулює своє бачення значення актів локальної нормотворчості в регулюванні праці у трьох основних аспектах. По-перше, це прояв принципу демократичності трудових відносин, відповідно до якого потреби й інтереси працівника безпосередньо впливають на нормативний зміст трудових відносин. По-друге, це засіб виховання правової культури працівника і роботодавця, а також їхньої взаємної відповідальності у трудоправових відносинах. По-трете, це реалізація вимоги правової визначеності, відповідно до якої суб'єктам трудових відносин має бути надана можливість легкого доступу до правових приписів, що визначають вимоги до їхньої поведінки, а також можливість використати локально-правові норми для захисту своїх прав та інтересів за необхідності.

Ключові слова: локальна нормотворчість, локальні нормативно-правові акти, трудові відносини, локальні норми, принцип демократичності, принцип правової визначеності.

\section{Summary}

Sirokha D. I. The importance of local norm-making acts in labor regulation. - Article.

The article contains an analysis of the essence of acts of local rulemaking and their influence on the legal regulation of labor. The author examines the concepts and approaches to local rulemaking in the doctrine of labor law. The article contains the author's concept of the importance of local rulemaking, which is formed on the basis of the analysis of legal acts and the results of scientific research.

The article states that only certain aspects of labor relations that reflect their specificity at a particular enterprise are included in the field of local rulemaking (for example, the establishment of internal labor rules, work schedules, etc.). Local legal norms are normative in nature. They represent the command of the authorized body of management, the general decisions of the employer and the trade union committee, the will of the labor collective. These norms, enshrined in the said documents, are the result of the relevant legal specialization, set for the purpose of specifying and detailing, taking into account the peculiarity of specific relations. Particular attention is paid to the legal nature of internal labor rules, technical rules and instructions.

The author formulates his vision of the importance of the acts of local rulemaking in the regulation of labor in three main aspects. First, it is a manifestation of the principle of the democracy of labor relations, according 
to which the needs and interests of the employee directly affect the normative content of labor relations. Secondly, it is a means of nurturing the legal culture of the employee and the employer, as well as their mutual responsibility in labor relations. Third, it is the implementation of the requirement of legal certainty, according to which the subjects of labor relations should be given the possi- bility of easy access to the legal regulations that determine the requirements for their behavior, as well as the ability to use local legal norms to protect their rights and interests in the case of need.

Key words: local norm-making, local normative-legal acts, labor relations, local norms, principle of democracy, principle of legal certainty. 